\title{
PRODUKTIVITAS KERBAU RAWA DI KECAMATAN MUARA MUNTAI, KABUPATEN KUTAI KARTANEGARA, KALIMANTAN TIMUR
}

\author{
PRODUCTIVITY OF SWAMP BUFFALO IN MUARA MUNTAI SUBDISTRIC, KUTAI \\ KARTANEGARA REGENCY, EAST KALIMANTAN
}

\author{
Komariah*, Kartiarso, dan Maria Lita \\ Departemen Ilmu Produksi dan Teknologi Peternakan, Fakultas Peternakan, Institut Pertanian Bogor, Jl. Rasamala \\ Kampus Dramaga, Bogor, 16680
}

\begin{abstract}
INTISARI
Penelitian yang dilaksanakan di kelompok peternakan kerbau Rawa Teluk Ridan Desa Pulau Harapan, Kecamatan Muara Muntai, Kabupaten Kutai Kartanegara ini bertujuan untuk mengkaji produktivitas kerbau Rawa di Muara Muntai, Kabupaten Kutai Kartanegara. Data produktivitas ditinjau dari aspek produksi dan reproduksi. Aspek produksi diteliti menggunakan 16 ekor kerbau Rawa yang terdiri atas pejantan, induk, anak jantan dan anak betina masing-masing 4 ekor. Rerata bobot badan anak kerbau umur 6-24 bulan adalah 201,58 $\pm 81,27 \mathrm{~kg}$ dan bobot dewasa umur 3-10 tahun adalah 372,66 $\pm 95,25 \mathrm{~kg}$. Aspek reproduksi diketahui dengan melakukan wawancara. Hasil yang diperoleh adalah sex ratio jantan/betina 1:4, umur birahi pertama 2,6 tahun dengan lama birahi 8 hari dan panjang siklus birahi 18,5 hari. Rerata birahi dan konsepsi pertama terjadi pada umur 2,8 tahun dengan lama kebuntingan 1 tahun. Angka kelahiran dan calf crop kerbau yaitu $75 \%$ dan $67 \%$, rerata kematian anak (mortalitas) $11 \%$ pada umur prasapih yaitu 1,7 bulan.
\end{abstract}

(Kata kunci: Kerbau Rawa, Produktivitas, Kabupaten Kutai Kartanegara)

\section{ABSTRACT}

The purpose of this research was to investigate productivity of Swamp buffalo at Pulau Harapan Village. The research was conducted at Muara Muntai Subdistric, Kutai Kartanegara Regency, East Kalimantan. The number of observation were 16 buffaloes. The results were as follow: the sex ratio between male and female was 1:4; first estrus was at 2.6 years old with the average duration of heat about 8 days and the estrus cycle about 18.5 days. The first mating at 2.8 years with the conception period about one year. Birth rate and calf crop were relatively high: $75 \%$ and $67 \%$. The mortality about $11 \%$ at 1.7 months old. An average body weight of calves at 0 to 24 months were $201.58 \pm 81.27 \mathrm{kgs}$ and adult buffaloes at 3-10 years were $372.66 \pm 95.25 \mathrm{kgs}$.

(Keywords: Swamp buffalo, Productivity, Kutai Kartanegara Regency)

\section{Pendahuluan}

Kerbau Rawa (Bubalus bubalis Linn.) merupakan salah satu komoditas peternakan yang potensial dalarn hal penyediaan daging karena pada kondisi pakan berkualitas rendah, mampu mencerna serat kasar lebih baik dari ternak sapi (Cockrill, 1974). Kerbau juga mempunyai persentase karkas yang relatif tinggi yaitu 40-47\% (Kristianto, 2006). Kabupaten Kutai Kartanegara merupakan salah satu daerah yang memiliki kerbau Rawa.

Kerbau di Muara Muntai tetap bertahan dan berkembangbiak dengan baik karena telah beradaptasi dengan lingkungan. Rerata kelembaban 59-71\% dan curah hujan per tahun $2076 \mathrm{~mm}$. Curah hujan terbanyak jatuh pada bulan Januari, Februari, Maret, dan April, sedangkan bulan kering jatuh pada bulan Juni, Agustus, dan September. Curah

\footnotetext{
* Korespondensi (corresponding author):

Telp. +62 8179910166

E-mail: komariah_purjati@yahoo.com
}

hujan maksimum $319 \mathrm{~mm}$ pada bulan Januari dan curah hujan minimum $26 \mathrm{~mm}$ jatuh pada bulan Juni. Kecepatan angin berkisar antara 8-61 km/jam, sedangkan arah angin selalu berubah-ubah dan terbanyak datang dari arah timur dan utara (Dinas Pertanian Kutai Kartanegara, 2008).

Beberapa alasan beternak kerbau Rawa yaitu sebagai sumber penghasilan, hobi/kegemaran, dan turun-temurun. Beternak kerbau merupakan pekerjaan utama, karena memiliki prospek sebagai sumber penghasilan yang tinggi dengan waktu pemeliharaan yang relatif singkat. Rerata pendapatan peternak dari hasil penjualan kerbau adalah diatas satu juta rupiah hingga mencapai 10 juta per bulan. Pendapatan ini dihitung berdasarkan hasil penjualan kerbau umur tiga tahun dan jumlah anak yang dihasilkan dibagi per bulan. Pekerjaan sambilan peternak yaitu sebagai nelayan (40\%), 
tukang kayu (20\%), pedagang (20\%), dan petani (10\%). Pekerjaan sambilan ini dilakukan saat musim kering (selain bulan Desember, Januari, Februari, Maret, dan April). Jenis ternak lain yang dipelihara oleh peternak adalah sapi dan ayam Bangkok. Dinas Peternakan Kutai Kartanegara (2007) melaporkan bahwa populasi dari tahun ke tahun tidak menunjukkan peningkatan yang signifikan bahkan menurun yaitu 4.515 ekor (2005), 2.043 ekor (2006), dan 2.149 ekor (2007), sedangkan konsumsi daging kerbau sebanyak $15.959 \mathrm{~kg}$ (Dinas Peternakan Kutai Kartanegara, 2008), sehingga perlu dilakukan berbagai cara untuk meningkatkan populasi ternak kerbau tersebut. Beberapa faktor penyebab rendahnya populasi kerbau di Indonesia pada umumnya adalah keterbatasan bibit unggul, mutu pakan rendah, perkawinan silang, dan kurangnya pengetahuan peternak dalam menangani produksi dan reproduksi ternak tersebut.

Pertumbuhan penduduk, pendapatan dan kesadaran mengenai pentingnya pangan berkualitas merupakan penyebab dilakukannya impor sapi beserta daging sapi dan komponen lainnya dalam rangka pemenuhan konsumsi daging. Kerbau diketahui memiliki beberapa kelebihan dibandingkan dengan sapi. Diwyanto dan Handiwirawan (2006) menyatakan bahwa kerbau dapat hidup di kawasan yang relatif sulit dalam keadaan pakan yang kurang baik. Kerbau juga dapat berkembangbiak dalam rentang agroekosistem yang luas dari daerah yang basah sampai daerah yang relatif kering.

Perubahan iklim berupa musim kering dan musim banjir mengakibatkan perbedaan penanganan dan sistem pemeliharaan ternak kerbau di Muara Muntai. Sistem pemeliharaan pada saat musim kering untuk semua kerbau adalah ekstensif, sedangkan pada musim banjir pemeliharaan kerbau dengan sistem semiintensif dan intensif.

Pemeliharaan dengan sistem ekstensif pada musim kering dan musim banjir memiliki perbedaan penanganan. Pemeliharaan kerbau secara ekstensif pada musim kering yaitu semua kerbau baik anak maupun dewasa dibiarkan liar ke rawa-rawa atau hutan yang berjarak $\pm 2 \mathrm{~km}$ dari kalang. Ternak yang diliarkan tersebut akan kembali ke kalang jika terjadi banjir. Pemeliharaan kerbau pada musim banjir dengan sistem intensif terutama pada anak $<6$ bulan, induk bunting dan induk menyusui. Anak dan induk tersebut dipelihara dengan sistem intensif, selalu berada di kalang dan diberi pakan hijauan tanpa penggembalaan. Kerbau yang digembalakan akan dikandangkan pada malam hari tanpa pemberian pakan. Peternak pada pagi hari berangkat dari rumah sekitar pukul 07.30 WITA untuk mencari hijauan kumpai (Hymenachne amplexicaulis (Rudge) Nees) di rawa-rawa yang jaraknya cukup jauh dari rumah. Perjalanannya harus melintasi sungai dengan menggunakan perahu dan memerlukan waktu kira-kira 30 menit. Sumber hijauan sekitar 1-2 km dari peternakan. Hijauan yang diambil $100 \%$ rumput lokal kumpai, karena disukai ternak. Ternak kerbau akan dilepaskan ke rawa penggembalaan, kecuali anak umur di bawah 3 bulan, induk bunting tua, dan induk menyusui. Hijauan kemudian diangkat dari perahu motor dan diletakkan di bagian kandang depan yang telah kosong karena kerbau telah turun. Kandang dibersihkan dengan menyemprotkan air menggunakan pompa air yang disedot dari bawah kalang. Kerbau istirahat di hutan pinggir rawa sekitar pukul 12.30-14.00 WITA.

Pakan yang dikonsumsi oleh kerbau hanya berupa hijauan dan tidak mendapat tambahan konsentrat. Konsentrat tidak diberikan karena tidak tersedianya bahan baku dan pengolah konsentrat. Kelapa sawit banyak terdapat di Kecamatan Muara Muntai tetapi pengolahannya di luar Muara Muntai sehingga hasil sampingannya tidak dapat digunakan sebagai konsentrat untuk pakan kerbau Rawa. Rumput yang merupakan pakan utama kerbau Rawa adalah rumput lokal kumpai (Hymenachne amplexicaulis (Rudge) Nees).

Kandungan nutrisi yaitu protein kasar (PK) dan TDN pada rumput kumpai masing-masing adalah 11,89 dan 59,73\% (Reksohadiprodjo, 1988) lebih tinggi dibanding dengan rumput yang lazim digunakan untuk pakan ternak yaitu Pennisetum purpureum dan Panicum maximum. Hal ini didukung oleh penelitian Susilawati (2003) yang menyatakan bahwa rumput lokal kumpai perlu dikembangkan sebagai hijauan pakan ternak karena memiliki nilai biologis yang tinggi dengan kandungan protein kasar $14,11 \%$ di habitat aslinya (rawa) dan memiliki daya cerna lebih baik daripada rumput gajah. Pihak Dinas Peternakan telah mengupayakan penanaman rumput gajah (Pennisetum purpureum), namun demikian upaya ini kurang berpengaruh terhadap penyediaan hijauan karena belum dimanfaatkan secara optimal oleh peternak dan keterbatasan pengetahuan untuk penanaman rumput ini. Rumput kumpai merupakan hijauan terbanyak yang ditemukan di rawa penggembalaan. Hijauan makanan ternak di Pulau Harapan tersedia cukup banyak untuk memenuhi kebutuhan ternak karena lahan yang tersedia luas dan hijauan tersedia sepanjang tahun. Peternak memberi hijauan dengan memotong rumput di daerah rawa dan membawa ke kalang. Sistem pemberian hijauan tersebut dikenal dengan istilah "cut and carry".

Pemberian tambahan mineral berupa garam diberikan hanya untuk induk yang sedang menyusui. Pemberian garam dipercaya dapat meningkatkan jumlah air susu induk. Pemberian 
hijauan untuk 15 ekor anak kerbau sebanyak satu perahu atau sekitar $300 \mathrm{~kg}$. Frekuensi pemberian hijauan rerata hanya sekali yaitu pada pagi hari menjelang siang atau sekitar pukul 10.00 WITA setelah ternak kerbau muda dan dewasa dilepas ke tempat penggembalaan.

Penelitian ini dilakukan dengan tujuan untuk mengetahui produktivitas kerbau Rawa dan perkembangan populasinya di Kabupaten Kutai Kartanegara dengan melihat kinerja produksi dan repoduksinya.

\section{Materi dan Metode}

Obyek penelitian adalah kerbau Rawa (Swamp buffalo) dan peternak kerbau Rawa di desa Pulau Harapan, Kecamatan Muara Muntai, Kabupaten Kutai Kertanegara. Pengambilan sampel pada penelitian ini dilakukan terhadap peternak aktif dengan metode purposive sampling. Responden dipilih secara sengaja berdasarkan kesediaan peternak untuk diwawancarai dengan penekanan pada kekayaan informasi yang dimiliki dan relevansinya dengan kajian. Data sekunder diperoleh dari Dinas Peternakan dan instansi terkait dengan penelitian ini. Teknik pengumpulan data menggunakan metode wawancara dengan menggunakan kuesioner. Pengukuran panjang badan dan lingkar dada kerbau dengan mengambil sampel secara acak sebanyak 16 ekor yang terdiri atas pejantan, induk, anak jantan dan anak betina masing-masing 4 ekor.

Metode yang digunakan untuk menduga bobot badan ternak kerbau adalah regresi linier berganda yang meliputi lingkar dada $(\mathrm{cm})$ dan panjang badan $(\mathrm{cm})$ berdasarkan Putra (1985).

$$
\log Y=B_{0}+B_{1} \log X_{1}+B_{2} \log X_{2}+e
$$

$$
\begin{array}{ll}
\text { Keterangan: } \\
\mathrm{Y} & : \text { bobot badan ternak }(\mathrm{kg}) \\
\mathrm{X}_{1} & : \text { lingkar dada }(\mathrm{cm}) \\
\mathrm{X}_{2} & : \text { panjang badan }(\mathrm{cm}) \\
\mathrm{B}_{0} & :-3,686 \text { (konstanta) } \\
\mathrm{B}_{1}, \mathrm{~B}_{2} & : \text { koefisien regresi } \\
\mathrm{B}_{1} & : 1,937 \\
\mathrm{~B}_{2} & : 0,902 \\
\mathrm{e} & : \text { error/tingkat kesalahan }
\end{array}
$$

Peubah yang diamati adalah aspek produksi dan reproduksi. Aspek reproduksi adalah rasio jantan dan betina (data primer), umur pubertas, siklus birahi dan lama birahi, umur kawin pertama, angka kebuntingan, lama bunting, calf crop, birahi setelah kelahiran, dikawinkan kembali setelah beranak dan selang beranak (calving interval). Pengukuran bagian-bagian tubuh untuk estimasi bobot badan sebagai indikator produksi didasarkan pada metode McNitt (1983). Pengukuran morfologi yang dilakukan meliputi: 1) Panjang badan, diukur dari tonjolan bahu (humerus) sampai tonjolan tulang duduk (tuber ischi) dengan menggunakan tongkat ukur. 2) Lingkar dada, diukur melingkar bagian dada tepat di belakang siku kaki depan tegak lurus terhadap sumbu dengan menggunakan pita ukur.

\section{Hasil dan Pembahasan}

\section{Keadaan iklim}

Muara Muntai ditinjau dari letak wilayah masih berada di bawah garis katulistiwa dengan iklim tropis basah yang terletak antara $116,22^{\circ} \mathrm{BT}$ dan $0,20^{\circ}$ LS dan terletak pada ketinggian $15-500$ di atas permukaan laut. Suhu rerata $31^{\circ} \mathrm{C}$, dengan suhu tertinggi $35^{\circ} \mathrm{C}$ dan suhu terendah $24^{\circ} \mathrm{C}$, sedangkan suhu umum adalah $33^{\circ} \mathrm{C}$ pada siang hari dan $22^{\circ} \mathrm{C}$ pada malam hari. Fahimuddin (1975) menyatakan bahwa zona nyaman untuk kerbau berkisar antara $15,5-21,0^{\circ} \mathrm{C}$, jika suhu udara lebih dari $24^{\circ} \mathrm{C}$ kerbau sudah mengalami stres dan batas kritis bagi mekanisme termoregulasi $36,50^{\circ} \mathrm{C}$.

\section{Karakteristik peternak}

Umur peternak yang menjadi responden bervariasi. Umur 25-35 tahun sebanyak 3 orang (30\%), umur 36-45 tahun sebanyak 6 orang (60\%) dan umur di atas 45 tahun sebanyak 1 orang (10\%). Hal ini menunjukkan bahwa umur peternak masuk dalam kisaran umur produktif karena umur produktif berkisar antara 20-55 tahun. Tingkat pendidikan merupakan salah satu faktor penting dalam mengembangkan sumber daya peternak. Pendidikan akan menambah pengetahuan dan keterampilan sehingga akan meningkatkan produktivitas kerja yang akan menentukan keberhasilan usaha. Hasil penelitian menunjukkan bahwa peternak memiliki latar belakang pendidikan SD $20 \%$, SMP/sederajat 40\%, dan SMA 40\%. Hal ini menunjukkan bahwa tingkat pendidikan yang ditempuh oleh peternak relatif tinggi dibandingkan daerah lain yang pada umumnya tidak menempuh pendidikan atau hanya berpendidikan SD.

\section{Keadaan ternak kerbau}

Jumlah ternak kerbau yang digembalakan dari 10 responden sebanyak 351 ekor dengan jumlah jantan 63 ekor dan betina 268 ekor (rasio 1:4). Jumlah ternak kerbau betina lebih banyak dipelihara karena jantan dianggap tidak dapat memberi nilai tambah berupa anak dibandingkan dengan betina. Kerbau jantan umumnya dijual pada umur 3 tahun. 


\section{Produktivitas ternak kerbau}

Reproduksi ternak kerbau. Karakteristik reproduksi ternak kerbau di Muara Muntai disajikan pada Tabel 1. Perbandingan jantan dan betina dapat dikatakan tinggi karena setiap ekor pejantan berbanding dengan empat ekor betina. Hal ini menunjukkan bahwa jumlah ternak jantan relatif banyak. Pejantan sebanyak 25\% memberi dampak terhadap produksi anak. Ternak betina hanya memiliki peluang menghasilkan anak maksimal $75 \%$ tiap tahunnya dari populasi. Banyaknya pejantan juga dapat menimbulkan persaingan untuk mengawini ternak betina yang dapat berakibat perkelahian pejantan. Kerbau betina yang sedang birahi akan dikelilingi 5-6 ekor pejantan dan kemungkinan betina akan dikawini oleh beberapa pejantan sehingga perkawinan tidak efektif. Perkelahian pejantan dapat berakibat negatif karena pejantan akan mengalami luka atau memar serta menghabiskan energi dalam tubuh yang mestinya diubah menjadi daging. Banyaknya jumlah pejantan tanpa seleksi akan menimbulkan kemungkinan adanya pejantan yang tangguh namun tidak memiliki produktivitas yang baik. Hal ini akan berakibat terhadap keturunan selanjutnya yaitu terjadinya inbreeding. Inbreeding tidak dikehendaki karena dapat menurunkan produktivitas ternak. Hal ini merupakan salah satu langkah kebijakan perbibitan ternak yang dilakukan pemerintah dan mengacu pada UU No. 2 tahun 1999 dan PP No. 5 tahun 2000 bahwa pemerintah memiliki kewenangan mencegah terjadinya inbreeding yang dapat mempengaruhi penyediaan bibit di masa mendatang (Departemen Pertanian, 2008). Banyaknya pejantan juga tidak efisien dalam segi ekonomi. Perbandingan jantan : betina diusahakan adalah 1:8-10 ekor (Departemen Pertanian, 2008).

Ranjhan dan Pathak (1979) menyatakan bahwa umur kawin pertama dan birahi pertama dianggap sama karena sistem perkawinan kerbau Rawa ini secara alami dan tidak ada perhatian khusus terhadap kegiatan reproduksi kerbau, sehingga dimungkinkan bahwa pada saat birahi pertama, kerbau langsung kawin atau terjadi konsepsi. Umur konsepsi pertama dapat dianggap sebagai perkiraan umur birahi pertama (walaupun kemungkinan kurang daripada itu). Birahi dan konsepsi pertama rerata terjadi pada umur 2,8 tahun. Umur kawin pertama ada yang mencapai 4 tahun walaupun dalam jumlah kecil, hal ini diestimasi berdasarkan umur kerbau. Pemberian pakan yang lebih baik yaitu dengan penambahan konsentrat sebanyak $5 \mathrm{~kg} / \mathrm{ekor} / \mathrm{hari}$ dapat meningkatkan bobot badan dan memperbaiki kondisi tubuh kerbau betina sehingga pada akhirnya dapat merangsang aktivitas birahi, konsepsi dan produksi

Tabel 1. Karakteristik reproduksi ternak kerbau di desa Pulau Harapan (the reproduction characteristic of buffalo in Pulau Harapan village)

\begin{tabular}{lcc}
\hline \hline \multicolumn{1}{c}{ Sifat reproduksi (reproductivity) } & $\begin{array}{c}\text { Hasil pengamatan } \\
\text { (observation) }\end{array}$ & $\begin{array}{c}\text { Literatur } \\
\text { (references) }\end{array}$ \\
\hline Rasio jantan : betina (sex ratio male:female) & $1: 4$ & $1: 8-10^{1}$ \\
Umur birahi pertama (first estrus) & 2,8 tahun & $2-3$ tahun $^{2}$ \\
Umur kawin pertama (first conception) & 2,8 tahun & $2,5-3$ tahun $^{2}$ \\
Lama birahi (estrus duration) & - & $36 \mathrm{jam}^{2}$ \\
Panjang siklus birahi (estrus cycle) & 18,5 hari & $21-24$ hari $^{3}$ \\
Service per conception & - & $1,6-2,0^{4}$ \\
Angka kebuntingan (conception rate) & - & $63 \%^{5}$ \\
Lama kebuntingan (conception period) & 365 hari & $310-315 \mathrm{hari}^{4}$ \\
Persentase kelahiran (calving rate) & $75 \%$ & $54,69 \%^{6}$ \\
Calf crop & $67 \%$ & $33 \% \%^{7}$ \\
Tingkat kematian anak (mortility) & $11 \%$ & $7,38 \%{ }^{6}$ \\
Umur kematian anak (calving mortility age) & 1,7 bulan & - \\
Birahi kembali setelah melahirkan (post partum estrus) & 1,0 bulan & 40 hari $^{8}$ \\
Selang beranak (calving interval) & 13,0 bulan & 1,5 tahun $^{9}$ \\
\hline
\end{tabular}

${ }^{1}$ Departemen Pertanian (2008)

${ }^{2}$ Rohaeni et al. (2008)

${ }^{3}$ Sosroamidjojo dan Soeradji (1990)

${ }^{4}$ Toelihere $\left(1981^{\mathrm{b}}\right)$

${ }^{5}$ Cockrill (1974)

${ }^{6}$ Hardjosubroto (1984)

${ }^{7}$ Hasanatun et al. (2005)

${ }^{8}$ National Research Council (1981)

${ }^{9}$ Guzman (1980). 
anak (Putu, 2003). Nutrisi yang sangat menunjang untuk saluran reproduksi, diantaranya: protein, vitamin A, dan mineral/vitamin (phosphor, kopper, kobalt, manganese, iodine, dan selenium) (Departemen Pertanian, 2007). Lama birahi dan panjang siklus birahi tidak diketahui karena selain kurangnya pengetahuan dan perhatian peternak mengenai hal ini, juga disebabkan oleh sifat birahi kerbau yang silent heat (birahi tenang). Tanda-tanda birahi pada kerbau hampir sama dengan sapi, tetapi tidak sejelas pada sapi (Sosroamidjojo dan Soeradji, 1990) dan tanda birahi semakin tidak nyata selama bulan kering dari April sampai Juni dan sering disebut silent heat (Ranjhan dan Pathak, 1979). Siklus birahi walaupun terutama diatur oleh hormon yang dihasilkan secara internal, ada juga faktor lain yang berpengaruh baik langsung maupun tidak langsung. Williamson dan Payne (1993) menyatakan bahwa faktor yang paling penting mempengaruhi siklus birahi di luar abnormalitas karena penyakit adalah tingkat pakan, panjangnya siang dan temperatur lingkungan. Service per conception (S/C) dan angka kebuntingan juga tidak diketahui. Hal ini karena kerbau Rawa yang terdapat di Muara Muntai tidak diinseminasi buatan (IB) atau kawin alam. Nilai S/C diperoleh dengan perhitungan jumlah perkawinan inseminasi buatan atau kawin alam yang dibutuhkan oleh seekor betina sampai terjadinya kebuntingan (Toelihere, $1981^{\mathrm{a}}$ ). Angka kebuntingan tidak diketahui karena tidak dilakukannya palpasi rektal pada 40-60 hari dan juga tidak adanya inseminasi buatan. Palpasi juga sulit dilakukan pada peternakan ini karena kerbau jarang dikandangkan atau rerata hidupnya di alam bebas. Nilai S/C dan angka kebuntingan adalah 1,6-2,0 dan 63\% (Toelihere, 1981 ${ }^{\text {b }}$; Cockrill, 1974).

Lama kebuntingan tidak diketahui secara pasti, namun dari hasil wawancara dikatakan bahwa lama kebuntingan 365 hari. Indikasi ini diperoleh dengan mengetahui adanya anak yang dihasilkan oleh betina dewasa tiap kali terjadi banjir. Kerbau kembali ke kalang pada saat banjir. Lama kebuntingan menurut Sosroamidjojo dan Soeradji (1990) adalah 315 hari.

Persentase kelahiran kerbau di Muara Muntai sebesar $75 \%$. Faktor yang mempengaruhi persentase kelahiran adalah keberhasilan perkawinan antara jantan dan betina. Persentase kelahiran dihitung dari jumlah total anak yang lahir tiap tahun dari persentase betina dewasa. Rerata persentase kelahiran anak kerbau di Indonesia adalah 54,69\% (Hardjosubroto, 1984). Calf crop atau panen anak adalah persentase jumlah anak yang hidup saat lepas sapih dalam satu tahun dari seluruh induk yang diteliti. Calf crop ternak kerbau di Muara Muntai lebih tinggi yaitu 67\% dibandingkan dengan panen anak hasil penelitian Ketaren (1999) di Kabupaten Garut yaitu Desa Bojong sebesar 28\% dan Desa Cibunar sebesar 50\%. Ketepatan waktu kawin merupakan salah satu faktor yang mempengaruhi tingginya panen anak di Muara Muntai karena sistem penggembalaan koloni dan banyaknya jantan yang tersedia. Faktor lain yang juga mempengaruhi adalah jarangnya terjadi penyakit baik pada betina maupun pejantan. Sakit dan penyakit berpengaruh terhadap panen anak, karena dapat mengakibatkan tidak terjadinya pembuahan pada rahim, kematian janin, kematian anak baik sebelum maupun setelah beranak (mortalitas anak). Waktu dan lama birahi serta nutrisi belum dapat diketahui pengaruhnya karena belum diketahuinya juga keterangan mengenai hal tersebut. Waktu yang diperlukan untuk birahi kembali setelah melahirkan adalah $45 \pm 12,25$ hari dan selang beranak $13 \pm 2,10$ bulan. Selang beranak kerbau di Muara Muntai termasuk dalam kisaran yang dinyatakan oleh Guzman (1980) yaitu antara 1-3 tahun atau rerata 1,5 tahun. Kematian ternak umumnya terjadi pada anak umur $0-3$ bulan yang diakibatkan terperangkap dalam semak atau lumpur dan kekurangan air susu. Hardjopranjoto (1991) menyatakan bahwa kematian pedet muda artinya kematian pedet pada umur kurang dari satu minggu dapat disebabkan oleh kekurangan pakan pada waktu kebuntingan muda, gangguan plasenta, gangguan kelahiran (distokia), pedet mengalami aspiksia hipertermia gangguan menyusui karena penolakan induknya, berat badan pedet yang rendah, infeksi bakteri, anemia atau defisiensi mineral yang diderita pedet dan kelahiran kongenital. Mortalitas kerbau di Muara Muntai $11 \%$, lebih tinggi dari rerata mortalitas yang terjadi di Indonesia sebesar 7,38\% (Hardjosubroto, 1984).

Produktivitas ternak kerbau. Pemeliharaan kerbau Rawa di Muara Muntai hanya memiliki satu tujuan produksi yaitu produksi daging. Hal ini dipengaruhi oleh keadaan lingkungan dan sistem pemeliharaan. Kerbau dibiarkan liar di rawa-rawa dan kurangnya lahan pertanian yang dapat memanfaatkan tenaga kerbau sehingga produksi kerbau terfokus untuk menghasilkan daging. Berbeda dengan daerah lain yang tujuan produksinya juga sebagai tenaga kerja, sumber pupuk, dan keperluan upacara adat.

Keistimewaan ternak kerbau dibandingkan dengan ternak ruminansia lainnya adalah kemampuan mencerna serat kasar lebih tinggi. Pertambahan berat badan kerbau dengan kondisi tersebut rerata per hari lebih tinggi dibandingkan dengan ternak sapi (Suharno dan Nazaruddin, 1994). Produktivitas kerbau disajikan pada Tabel 2.

Suman dan Sharma (2003) menyatakan bahwa kandungan protein daging kerbau yang 
digiling sebesar $21,14 \%$ dan kandungan lemak 8,4-8,53\% dengan nilai $\mathrm{pH}$ 6,07, sehingga dapat dikatakan bahwa daging kerbau memilki nutrisi tinggi. Neath et al. (2007) menyatakan bahwa daging kerbau lebih empuk daripada daging sapi pada umur yang sama.

Kinerja produksi kerbau dapat dilihat dan diukur dengan mengetahui bobot badan, ukuran tubuh, kondisi ternak dan kemampuan kerjanya. Bobot badan seekor ternak merupakan suatu aspek yang penting dalam pemilihan stock untuk breeding, feeding, dan marketing. Bobot badan ini perlu diketahui untuk menyusun ransum seekor ternak. Pemasaran ternak kerbau berdasarkan bobot hidup belum populer karena tidak selalu tersedia alat timbangan, karena alat timbangan cukup mahal harganya. Penentuan bobot badan yang tepat dari seekor ternak diperlukan juga oleh para dokter hewan untuk menentukan dosis obat, terutama apabila penggunaan obat tersebut dibatasi oleh therafeutic index dan bobot badan ternak. Pemberian obat berdasarkan perkiraan bobot badan yang kurang tepat akan membahayakan kesehatan ternak (Saladin, 1988).

Panjang badan dan lingkar dada merupakan gabungan parameter yang akurat dalam menduga bobot badan ternak kerbau. Ukuran panjang badan dan lingkar dada serta perkiraan bobot badan anak kerbau dan kerbau dewasa disajikan pada Tabel 3. Williamson dan Payne (1993) menyatakan bahwa pemakaian ukuran lingkar dada dan panjang badan dapat digunakan untuk estimasi bobot badan seekor hewan. Peningkatan bobot badan ternak diiringi dengan peningkatan panjang badan dan lingkar dada namun peningkatan lingkar dada lebih berkorelasi terhadap peningkatan bobot badan. Hasil penelitian Aisiyah (2000) membuktikan bahwa nilai korelasi tertinggi diperoleh dari lingkar dada dibandingkan dengan ukuran badan lainnya. Peningkatan ukuran lingkar dada memiliki korelasi yang lebih erat dengan peningkatan bobot badan kerbau karena sebagian besar bobot badan dipikul oleh kaki depan dan pertautan antara badan dan kaki diselenggarakan oleh otot-otot penggantung musculus serratus ventralis dan musculus pectoralis yang terletak di daerah dada. Bobot badan meningkat diikuti dengan semakin kuat dan subur otot-otot tersebut sehingga lingkar dada meningkat. Umur kerbau yang digunakan pada penelitian ini berkisar antara 6 bulan sampai 10 tahun. Bobot hidup meningkat seiring dengan bertambahnya umur. Hal ini terlihat jelas pada Tabel 3, bahwa semakin meningkat umur maka bobot badan semakin tinggi pula.

Tabel 2. Produktivitas kerbau (buffalo production)

\begin{tabular}{lcc}
\hline \hline \multicolumn{1}{c}{ Sifat produksi (productivity) } & Jumlah (total) & $\begin{array}{c}\text { Persentase (\%) } \\
\text { (percentage (\%)) }\end{array}$ \\
\hline Bobot hidup $(\mathrm{kg})$ (body weight $(\mathrm{kg}))$ & 370,00 & - \\
Bobot potong $(\mathrm{kg})$ (slaughter weight $(\mathrm{kg}))$ & 360,00 & 100,00 \\
Karkas panas $(\mathrm{kg})($ hot carcass $(\mathrm{kg}))$ & 171,50 & 47,60 \\
Karkas bagian depan $(\mathrm{kg})($ forequarter carcass $(\mathrm{kg}))$ & 70,56 & 56,42 \\
Karkas bagian belakang $(\mathrm{kg})($ hindquarter carcass $(\mathrm{kg}))$ & 54,52 & 43,58 \\
Non karkas $(\mathrm{kg})($ offal $(\mathrm{kg}))$ & 188,66 & 52,40 \\
Tebal lemak punggung $(\mathrm{mm})($ fat thickness $(\mathrm{mm}))$ & 3,50 & - \\
Luas otot mata rusuk $\left(\mathrm{cm}^{2}\right)\left(\right.$ rib eye area $\left.\left(\mathrm{cm}^{2}\right)\right)$ & - & - \\
\hline
\end{tabular}

Sumber: Miskiyah dan Usmiati (2005).

Tabel 3. Rerata ukuran tubuh kerbau di Muara Muntai (the mean of buffalo body condition in Muara Muntai)

\begin{tabular}{ccccc}
\hline \hline Kelompok/peubah (variable) & $\begin{array}{c}\text { Umur } \\
(\text { age })\end{array}$ & $\begin{array}{c}\text { Panjang badan }(\mathrm{cm}) \\
\text { (body length }(\mathrm{cm}))\end{array}$ & $\begin{array}{c}\text { Lingkar dada }(\mathrm{cm}) \\
\text { (heart girth }(\mathrm{cm}))\end{array}$ & $\begin{array}{c}\text { Bobot badan }(\mathrm{kg}) \\
(\text { body weight }(\mathrm{kg}))\end{array}$ \\
\hline Anak (bulan) (calf buffalo (month)) & 6 & $75,00 \pm 0,01$ & $103,00 \pm 15,56$ & $8,00 \pm 23,46$ \\
& 12 & $107,80 \pm 4,38$ & $149,60 \pm 6,84$ & $229,99 \pm 26,41$ \\
& 24 & $126,00 \pm 0,01$ & $160.00 \pm 0,01$ & $300,55 \pm 0,01$ \\
Rerata (average) & & $101,88 \pm 18,04$ & $139,25 \pm 2,98$ & $201,58 \pm 81,27$ \\
Dewasa (tahun) (buffalo (years)) & 3 & $115,50 \pm 0,71$ & $121,33 \pm 2,31$ & $136,67 \pm 5,77$ \\
& 4 & $160,00 \pm 0,01$ & $180,00 \pm 10,00$ & $186,67 \pm 23,09$ \\
Rerata (average) & $\geq 5$ & $277,86 \pm 1,53$ & $366,00 \pm 4,90$ & $442,53 \pm 115,51$ \\
& & $125,63 \pm 10,03$ & $177,50 \pm 17,53$ & $372,66 \pm 95,25$ \\
\hline
\end{tabular}


Hardjosworo dan Levine (1987) menyatakan bahwa rerata bobot kerbau jantan dan betina pada umur $0,1,2,3,4$ dan lebih dari 5 tahun masingmasing adalah $30,160,285,405,515$, dan $565 \mathrm{~kg}$. Peningkatan bobot badan dan laju pertumbuhan yang lebih tinggi, pada umur satu dan dua tahun memiliki bobot badan 229,99 $\pm 26,41 \mathrm{~kg}$ dan $300,55 \pm 0,01 \mathrm{~kg}$, sedangkan pada umur 3 sampai $>5$ tahun kerbau tersebut menunjukkan laju pertumbuhan yang menurun sehingga peningkatan bobot badan kerbau rendah. Rerata bobot badan anak kerbau umur 6-24 bulan adalah 201,58 $\pm 81,27$ $\mathrm{kg}$ dan dewasa umur 3-10 tahun adalah $372,66 \pm 95,25 \mathrm{~kg}$. Hal ini didukung oleh pernyataan Parakkasi (1997) bahwa faktor umur sangat berpengaruh terhadap laju pertumbuhan ternak. Umur menjelang dan sekitar pubertas, laju pertumbuhan umumnya optimal dan mendekati dewasa tubuh sedangkan laju pertumbuhan menurun. Penjualan kerbau umumnya pada umur 3 tahun. Hal ini mendukung penjualan dengan keuntungan yang optimum karena laju pertumbuhan kerbau semakin tua akan mengalami penurunan.

\section{Kesimpulan}

Rerata bobot badan anak kerbau umur 6-24 bulan adalah $201,58 \pm 81,27 \mathrm{~kg}$ dan dewasa umur 3-10 tahun adalah $372,66 \pm 95,25 \mathrm{~kg}$. Rerata birahi dan konsepsi pertama terjadi pada umur 2,8 tahun. Umur kawin pertama ada yang mencapai 4 tahun walaupun dalam jumlah kecil. Persentase kelahiran kerbau sebesar 75\%. Mortalitas anak kerbau $11 \%$ dengan rerata umur 1,7 bulan. Siklus birahi 18,5 hari, sedangkan sex ratio jantan:betina yaitu 1:4.

\section{Daftar Pustaka}

Aisiyah, N. 2000. Studi ukuran tubuh sapi Madura di Desa Samaran, Kecamatan Tambelayan, Kabupaten Sampang, Madura. Skripsi. Fakultas Peternakan, Institut Pertanian Bogor. Bogor.

Cockrill, W. 1974. The Husbandry and Health of the Domestic Buffalo: The Buffalo of Indonesia. Food and Agriculture Organization of the United Nations. Rome.

Departemen Pertanian. 2007. Petunjuk Teknis: Penanggulangan Gangguan Reproduksi pada Sapi Potong. Pusat Penelitian dan Pengembangan Peternakan. Pasuruan.

Departemen Pertanian. 2008. Road Map Perbibitan Ternak. Direktorat Perbibitan, Direktorat Jenderal Peternakan. Jakarta.
Dinas Pertanian Kutai Kartanegara. 2008. Keadaan Umum Wilayah Kecamatan Muara Muntai, Kutai Kartanegara. Dinas Peternakan, Kutai Kartanegara.

Dinas Peternakan Kutai Kartanegara. 2007. Populasi Ternak di Kabupaten Kutai Kartanegara. Dinas Peternakan, Kutai Kartanegara.

Dinas Peternakan Kutai Kartanegara. 2008. Inventarisasi Potensi Lahan Sektor Peternakan. Dinas Peternakan, Kutai Kartanegara.

Diwyanto, K. dan H. Handiwirawan. 2006. Strategi pengembangan ternak kerbau: Aspek penjaringan dan distribusi. Prosiding Lokakarya Nasional Usaha Ternak Kerbau Mendukung Program Kecukupan Daging Sapi. Pusat Penelitian dan Pengembangan Peternakan. Bogor.

Fahimuddin, M. 1975. Domestic Water Buffalo. Oxford and IBH Publishing. Co. G G Joupath. New Delhi.

Guzman, M. R. 1980. An overview of recent development in buffalo research and management in Asia. In: Buffalo Production for Small Farms. ASPAC. Taipei.

Hardjopranjoto, S. 1991. Permasalahan reproduksi pada sapi potong. Prosiding Seminar Nasional Sapi Potong di Indonesia. Dewan Pimpinan Pusat Perhimpunan Peternak Sapi dan Kerbau lndonesia. Bandar Lampung.

Hardjosubroto, W. 1984. Breed evaluation of large ruminants in Indonesia. In: Evaluation of Large Ruminants for The Tropics. J. W. Copland (ed). ACIAR Proceedings Series No. 5. Australia.

Hardjosworo, P. S. dan J. M. Levine. 1987. Pengembangan Peternakan Indonesia: Bangsa-Bangsa Ternak di Indonesia dan Hasilnya. Yayasan Obor Indonesia. Jakarta.

Hasanatun, Hasinah, dan E. Handiwirawan. 2005. Keragaman Genetik Ternak Kerbau di Indonesia. Pusat Penelitian dan Pengembangan Peternakan. Bogor.

Ketaren, G. W. 1999. Perencanaan pengembangan ternak kerbau di Kabupaten Pandeglang, Jawa Barat. Skripsi. Fakultas Peternakan, Institut Pertanian Bogor. Bogor.

Kristianto, L. K. 2006. Pengembangan perbibitan kerbau kalang dalam menunjang agrobisnis dan agrowisata di Kalimantan Timur. Prosiding Lokakarya Nasional Usaha Ternak Kerbau Mendukung Program Kecukupan Daging Sapi. Pusat Penelitian dan Pengembangan Peternakan. Bogor.

McNitt. 1983. Livestock Husbandry Techniques. Granada Publishing. New York. 
Miskiyah dan S. Usmiati. 2005. Potongan komersial karkas kerbau: Studi kasus di PT Kariyana Gita Utama-Sukabumi. Balai Besar Penelitian dan Pengembangan Pascapanen Pertanian. Bogor.

National Research Council. 1981. The Water Buffalo: New prospects for an underutilized animal. National Academy Press. Washington, D. C.

Neath, K. E., A. N. Del Barrio, R. M. Lapitan, J. R. V. Herrera, L. C. Cruz, T. Fujihara, S. Muroya, K. Chikuni, M. Hirabayashi and Y. Kanai. 2007. Difference in tenderness and $\mathrm{pH}$ decline between water buffalo meat and beef during postmortem aging. J. Meat Sci. 75: 497-505.

Parakkasi, A. 1997. Ilmu Nutrisi dan Makanan Ternak Ruminansia. Universitas Indonesia. Jakarta.

Putra, I. G. 1985. Pendugaan bobot hidup kerbau lumpur berdasarkan pengukuran morfologi. Tesis Program Pascasarjana. Institut Pertanian Bogor. Bogor.

Putu, I. G. 2003. Aplikasi Teknologi Reproduksi untuk Peningkatan Performans Produksi Ternak Kerbau di Indonesia. Balai Penelitian Ternak. Bogor.

Ranjhan, S. K. and N. N. Pathak. 1979. Management and Feeding of Buffaloes.Vikas Publishing House PVT, Ltd. New Delhi.

Reksohadiprodjo, S. 1988. Pakan Ternak Gembala. BPFE-Yogyakarta. Yogyakarta.
Rohaeni, E. S., M. Sabran, dan A. Hamdan. 2008. Potensi, peran dan permasalahan beternak kerbau di Kalimantan Selatan. Prosiding Seminar dan Lokakarya Nasional Usaha Ternak Kerbau. Puslitbang Peternakan bekerjasama dengan Direktorat Perbibitan, Direktorat Jenderal Peternakan, Dinas Peternakan Propinsi Jambi, Dinas Peternakan dan Perikanan Kabupaten Batanghari.

Saladin, R. 1988. Kerbau: Sebuah metode pengukuran berat badan. Dalam: Ternak dan Lingkungan. Jamarun, N. (ed). Pusat Penelitian Universitas Andalas. Padang.

Sosroamidjojo, M. S. dan Soeradji. 1990. Peternakan Umum. CV. Yasaguna. Jakarta.

Suharno, B. dan Nazaruddin. 1994. Ternak Komersial. Penebar Swadaya. Jakarta.

Suman, S. P. and B. D. Sharma. 2003. Effect of grind size and fat levels on the physicochemical and sensory characteristics of lowfat ground buffalo meat patties. J. Meat Sci. 65: 973-976.

Susilawati, E. 2003. Eksplorasi Rumput Kumpai (Hymenachine amplexicaulis (Rudge) Nees) sebagai Pakan Ternak di Provinsi Jambi. Balai Pengkajian Teknologi Pertanian. Jambi.

Toelihere, M. R. 1981 ${ }^{\text {a }}$. Fisiologi Reproduksi pada Ternak. Angkasa. Bandung.

Toelihere, M. R. 1981 ${ }^{\mathrm{b}}$. Inseminasi Buatan pada Ternak. Angkasa. Bandung.

Williamson, G. dan W. J. A. Payne. 1993. Pengantar Peternakan di Daerah Tropis. Terjemahan: Darmadja D. Gadjah Mada Press. Yogyakarta. 